\title{
A comprehensive framework for the assessment of new end uses in recycled water schemes
}

Zhuo Chen ${ }^{\mathrm{a}}$, Huu Hao $\mathrm{Ngo}^{\mathrm{a}, *}$, Wenshan Guo ${ }^{\mathrm{a}}$, Richard Lim ${ }^{\mathrm{b}}$, Xiaochang C. Wang ${ }^{\mathrm{c}}$, Kelly $\mathrm{O}^{\prime}$ Halloran ${ }^{\mathrm{d}}$, Andrzej Listowski ${ }^{\mathrm{e}}$, Nigel Corby ${ }^{\mathrm{f}}$, Clayton Miechel ${ }^{\mathrm{g}}$

${ }^{a}$ Centre for Technology inWater and Wastewater, School of Civil and Environmental Engineering, University of Technology Sydney, Sydney, NSW 2007, Australia

b School of the Environment, Faculty of Science, University of Technology Sydney, Sydney, NSW 2007, Australia

${ }^{c}$ Key Lab of Northwest Water Resources, Environment and Ecology, Ministry of Education, Xi'an University of Architecture and Technology, Xi'an 710055, China

${ }^{\mathrm{d}}$ Gold Coast City Council, Gold Coast MC, QLD 9726, Australia

e Sydney Olympic Park Authority, 7 Figtree Drive, Sydney, NSW 2127, Australia

${ }^{\mathrm{f}}$ City WestWater, 247-251 St. Albans Road, Sunshine, VIC 3020, Australia

${ }^{g}$ Port Macquarie-Hastings Council, P.O. Box 84, Port Macquarie, NSW 2444, Australia

Corresponding author. Tel.:+61 2 95142745; fax: +61 295142633.

E-mail addresses: h.ngo@uts.edu.au, HuuHao.Ngo@uts.edu.au (H.H. Ngo).

http://dx.doi.org/10.1016/j.scitotenv.2013.09.061

\section{Highlights}

- A framework for holistic assessment of new recycled water end uses was proposed.

- The potential and key issues for development of three new end uses were analysed.

- The alternative management strategies and evaluation criteria were discussed.

- The procedures and algorithms of multi-criteria analysis (MCA) were addressed.

- Quantitative models, surveys and case studies should be further performed.

\begin{abstract}
Nowadays, recycled water has provided sufficient flexibility to satisfy short-term freshwater needs and increase the reliability of long-term water supplies in many water scarce areas, which becomes an essential component of integrated water resources management. However, the current applications of recycled water are still quite limited that are mainly associated with non-potable purposes such as irrigation, industrial uses, toilet flushing and car washing. There is a large potential to exploit and develop new end uses of recycled water in both urban and rural areas. This can greatly contribute to freshwater savings, wastewater reduction and water sustainability. Consequently, the paper identified the potentials for the development of three recycled water new end uses, household laundry, livestock feeding and servicing, and swimming pool, in future water use market. To validate the strengths of these new applications, a conceptual decision analytic framework was proposed. This can be able to facilitate the optional management strategy selection process and thereafter provide guidance on the future end use studies within a larger context of the community, processes, and models in decision-making. Moreover, as complex evaluation criteria were selected and taken into account to narrow down the multiple management alternatives, the methodology can successfully add transparency, objectivity and comprehensiveness to the assessment. Meanwhile, the proposed approach could also allow flexibility to adapt to particular circumstances of each case under study.
\end{abstract}




\section{Keywords}

Recycled water; assessment framework; new end uses; decision making

\section{Introduction}

The growing environmental problems, including the diminishing natural water resources, greater water demand triggered by population growth and urbanisation, deteriorated water quality, and highly changing climate, have highlighted the importance of exploiting all other possible water sources before using-up limited surface water and groundwater supplies. Recycled water, which is the wastewater being treated to a specified quality in order to be reused again, has been increasingly considered as a supplementary water supply (Lazarova et al., 2003 and DWR (Department of Water Resources), 2009). The merits of recycled water use have been demonstrated all over the world. In addition to economic, social and environmental benefits, a distinct benefit of water reuse is the steadiness of water supply for both household and local industries, which is superior to rainfall-dependent water sources (Lazarova et al., 2012). Moreover, when bringing recycled water and other water resources together in management, the ecological footprint of water, sewage and drainage system could be potentially reduced by over $25 \%$ (Anderson, 2003). In a broader sense, water management can be further incorporated into climate change adaptation and environmental sustainable development (Angelakis and Durham, 2008 and Asano and Bahri, 2011). However, despite apparent strengths of recycled water, the further adoption of water reuse might be affected by a variety of issues, including water rights, environmental concerns, public acceptance, and cost (NRC, 2012).

In developed countries, especially the cities and regions where freshwater resources are approaching the sustainable limit, recycled water would continue to be an important alternative water resource, especially for non-potable purposes (Chen et al., 2013a). More stringent water treatment standard (e.g., tertiary treatment and additional nutrient removal) is expected to be required in most recycled water schemes. As highly advanced technologies are available for producing clean water from wastewater without adverse health effects, the focus of motivating water reuse should shift away from technological issues to environmental, social and economic concerns (Van der Bruggen, 2010). While agricultural and industrial purposes are the dominant end uses of recycled water presently, urban and residential applications such as landscape irrigation, toilet flushing and car washing, are experiencing rapid development, the amount of which are likely to be as high as or much higher than that of agricultural irrigation schemes (Brissaud, 2010 and Wild et al., 2010). High value end uses with potential close human contact (e.g., recycled water for household laundry and swimming pools) would be promising but still somewhat ambiguous due to strong public misgivings. Comparatively, in less developed countries, owing to technical and economic constraints, a large proportion of water reuse activities still involve secondary wastewater treatment. There would be a tendency in recycled water market towards higher level of treatment. With respect to end uses, apart from agricultural irrigation that will continue to be the major user of recycled water, other agricultural activities such as livestock consumption, using recycled water, can be beneficial to alleviate freshwater stress and maintain economic development. According to these recent trends in both developed and developing areas (Chen et al., 2013a), current end uses are mostly limited to a few non-potable purposes. To meet aggressive water recycling targets, beyond the implementation of more recycled water schemes, the development of new end uses might be prospective and should be realised accordingly. 


\section{Proposed methodology for assessing new end uses of recycled water}

A systematic framework for the evaluation of new recycled water end uses was established with a full assessment procedure that follows the characteristic multi-criteria analysis (MCA) decision-making process in water resource management (Alvarez-Guerra et al., 2010). According to Fig. 1, the framework consists of three phases, where phase 1 is the primary screening step to identify the prospects of specific new end uses and verify the viability through initial qualitative approach. Phase 2 starts with the development of several management alternatives which employ different facilities, equipment and/or varied treatment technologies towards one/several end use(s). After selection of particular evaluation criteria from five identified categories, phase 2 involves the application of multi-criteria analysis (MCA) to further prioritise the management options. Finally, phase 3 is the management step that includes the result discussion, communication, review and reporting.

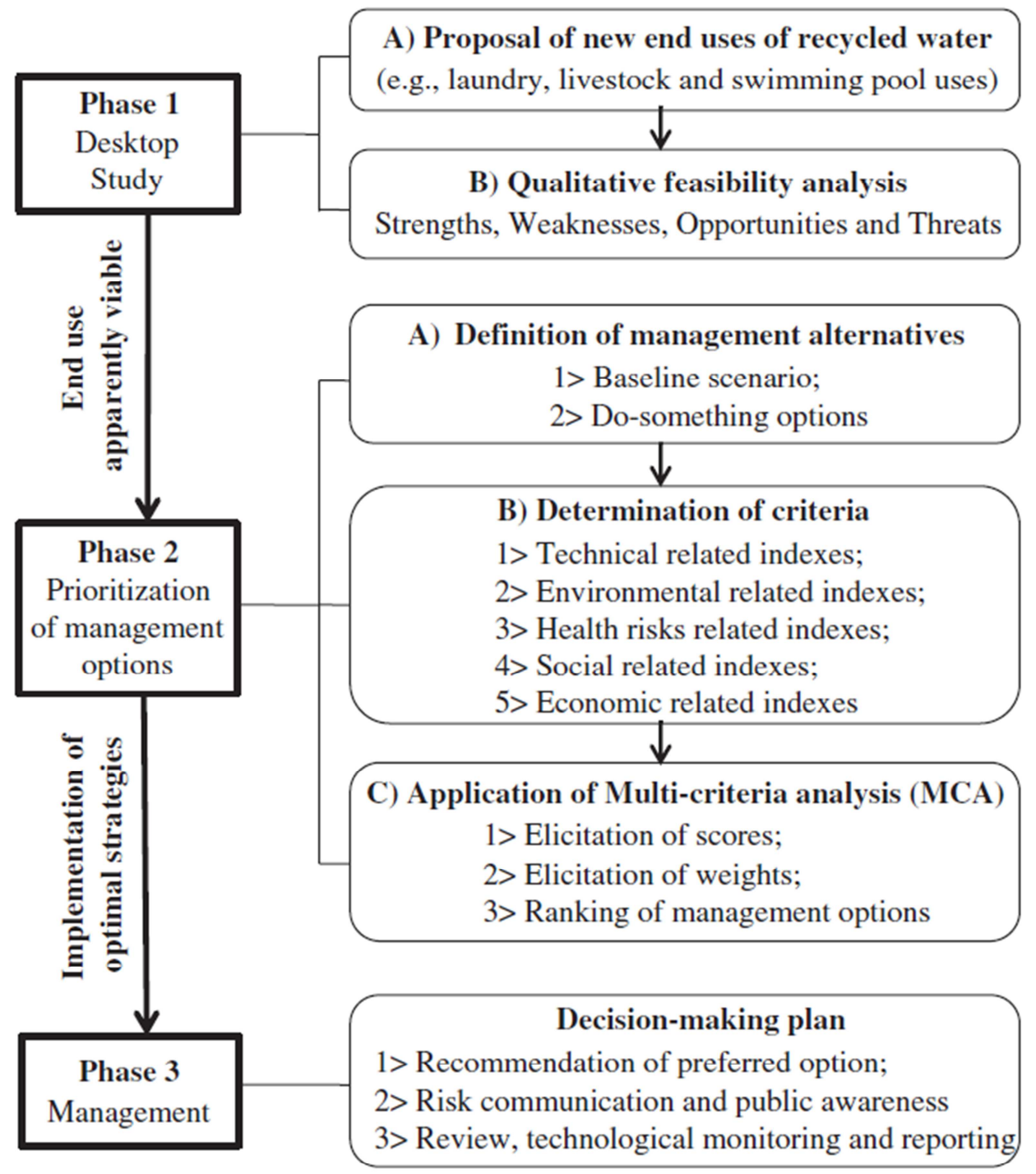

Fig. 1. Proposed framework for decision making in new end use management. (Modified from Chen et al, 2012a.) 


\section{Identification of potentials for the development of recycled water new end uses}

\subsection{Use of recycled water for household laundry}

Generally, household laundry accounts for 15-20\% of household water usage and is regarded as the second largest indoor user of water (Babin, 2005 and Savewater Alliance, 2012). However, the water consumption for laundry in different households may vary substantially due to the variety of washing machine types, number of washes, wash temperatures, load sizes, etc. Table 1 summarises the different household behaviours in laundry worldwide. In Europe and Turkey, most of the households employ the state-of-art front loading washing machines with integrated heating rods, using electricity to heat-up water internally. Turkish households even use high wash temperatures more frequently, where more than $75 \%$ of the clothes are washed at water temperatures higher than $50{ }^{\circ} \mathrm{C}$. While in Asia, North America and Australia, top loading washing machines are widespread which use water from external cold and/or warm water taps that is not heated by the washing machine further. Due to the traditional laundry habits and practices, low wash temperatures have been widely adopted in these countries (Pakula and Stamminger, 2010). In Australia, the percentage of cold water used by washing machine was over $70 \%$ and varied between 70 and $90 \%$ (Bertone and Stewart, 2011). As the choice of washing machine type is the main factor affecting the annual water consumption in laundry and front loaders typically consume less than half as much water per wash as top loaders, European households use significantly less amount of water than Asian and North American households. However, they consume additional electricity and/or energy to heat-up water from the cold water tap.

\begin{tabular}{|c|c|c|c|c|c|c|}
\hline East Europe & $>98 \%$ Front & $3-4^{a}$ & 40 & 60 & 173 & 10.4 \\
\hline Turkey & $>90 \%$ Front & - & 60 & 60 & 211 & 12.7 \\
\hline North America & $>98 \%$ Top & $3-4$ & $15-48$ & 144 & 289 & 41.6 \\
\hline Australia & $>68 \%$ Top & - & $20-40$ & 106 & 260 & 27.6 \\
\hline Japan & $>97 \%$ Top & $\sim 3$ & Cold water & 120 & 520 & 62.4 \\
\hline
\end{tabular}

Modified from Pakula and Stamminger (2010): ABS (2011).

Abbreviations: phpy $=$ per household per year; Front $=$ front loader; Top $=$ top loader

${ }^{a}$ Indicate $75 \%$ of machine capacity.

Overall, more than 9.9 kilolitres $(\mathrm{kL})$ of fresh water can be saved per household per year worldwide if recycled water could be reticulated to the cold water input tap to the washing machine. The installation of an additional recycled water tap and the upgrade of recycled water treatment plant due to increased demand would incur extra charges. However, considering the total resource cost and operating/maintenance cost perspectives, the life cycle unit cost of the proposed new laundry use scenario might be financially viable. Moreover, the water authorities will also benefit from this new end use as the treated recycled water can be utilised more efficiently and result in higher revenue rather than being directly discharged to the environment (Bertone and Stewart, 2011). When it comes to water quality, the Class A recycled water which undergoes tertiary treatment has been proved to be suitable for washing clothes (YVW, 2010). Particularly, DOH (2013) prescribed that the microbial contents of the Escherichia coli, somatic bacteriophage and Cryptosporidium should be less than $1 \mathrm{cfu}$ per $100 \mathrm{~mL}, 1$ pfu per $100 \mathrm{~mL}$ and 1 oocyst per $1 \mathrm{~L}$, respectively. In terms of heavy metal concentrations, Mainali et al. (2013) indicated that $1 \mathrm{mg} / \mathrm{L}$ of iron $(\mathrm{Fe}), 1 \mathrm{mg} / \mathrm{L}$ of lead $(\mathrm{Pb})$, $10 \mathrm{mg} / \mathrm{L}$ of zinc $(\mathrm{Zn}), 5 \mathrm{mg} / \mathrm{L}$ of copper $(\mathrm{Cu})$ and $1 \mathrm{mg} / \mathrm{L}$ of manganese $(\mathrm{Mn})$ are the 
maximum allowable values for the recycled water use in household laundry in terms of tensile and tearing strengths.

\subsection{Use of recycled water for livestock feeding and servicing}

While recycled water in household laundry could be a considerable contributor to freshwater savings, especially in highly populated urban areas if managed properly, there is also a great potential to exploit and implement new end uses in rural and regional areas. For instance, Fig. 2 shows that less than $2 \%$ of annual water consumption on livestock farming activities in Australia is sourced from recycled water, compared with $61 \%$ and $37 \%$ from self-extracted and distributed water sources (e.g., surface water and groundwater), respectively (ABS, 2012). The total volume of water consumed by agricultural industry will grow fast, which is expected to rise $14 \%$ in the next 30 years, putting more pressure on dwindling water resources (UN, 2010). As the global water demand is likely to exceed supply by $56 \%$ by the year 2025 (WWO, 2010), there would be a significant decrease in agricultural productivity, especially during the time when prolonged drought and continuing unavailability of water happen. Since the water requirement for livestock industry is high, from feed production to servicing and product supply processes, the related recycled water application should be taken into account to further expand the recycled water market in nonmetropolitan areas.

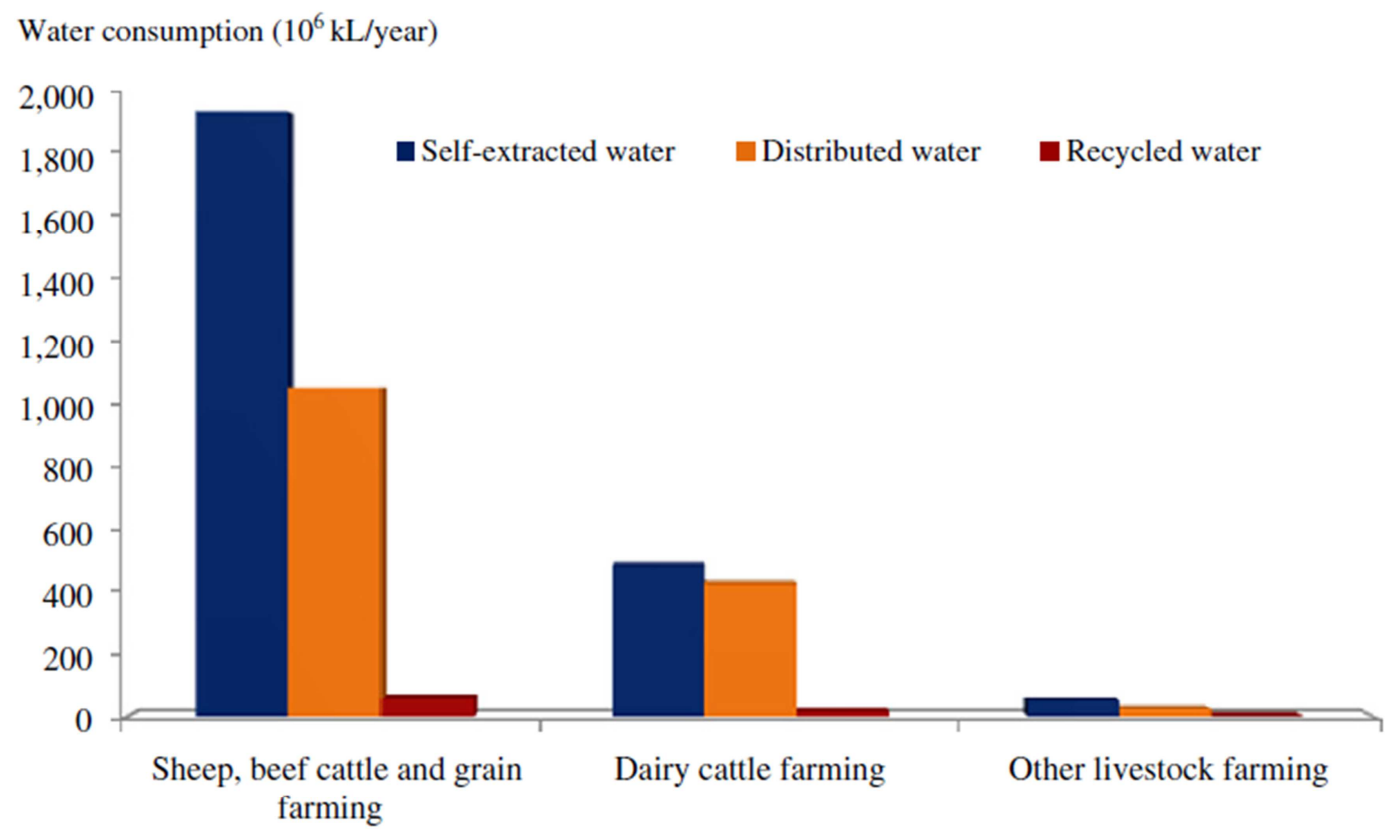

Fig. 2. Water consumption on livestock farming activities in Australia by different origins of water (ABS, 2012).

Particularly, livestock have to maintain their vital physiological functions with water content higher than 60 to $70 \%$ of the body weight. Reduction of water intake can result in lower meat, milk and egg production as well as weight loss. Drinking water is the prime way to meet the daily water requirements despite that livestock are able to ingest water contained in hydrated feedstuffs and/or absorb the metabolic water produced by oxidation of nutrients. Table 2 gives the water use information of different stocks. As can be seen, water needs vary because of the discrepancies of the animal species, breed, age, weight, the level of dry matter intake, the physical form of the diet, water availability and quality, temperature of the supply water, ambient temperature and the farming system. Given that the water demand 
increases linearly with age and becomes constant after animal reaches adulthood (Chapagain and Hoekstra, 2003), the rough daily drinking water demand of an animal can be estimated in Eqs. (1) and (2). In some cases, water requirements can be extremely high for highly productive animals under warm and dry conditions due to increased water losses with high temperature and low humidity (FAO, 2006).

$$
\begin{aligned}
& \text { For Age }<\text { Age }_{\text {adult }}: q_{d}[e, a]=\left(\frac{q_{\max }[e, a]-q_{\min }[e, a]}{\operatorname{Age}_{\text {adult }}}\right) \times \text { Age } \\
& +q_{\text {min }}[e, a]
\end{aligned}
$$

$$
\text { For Age }>\text { Age }_{\text {adult }}: q_{d}[e, a]=q_{\max }[e, a]
$$

where,

$q_{d}[e, a]$ is the daily drinking water requirement of animal a in exporting country e.

$q_{\max }[e, a]$ and $q_{\min }[e, a]$ are the average daily drinking water requirements of an adult and a body animal respectively.

Age $_{\text {adult }}$ is the age of an animal in days when adult (Chapagain and Hoekstra, 2003).

\begin{tabular}{|c|c|c|c|c|c|}
\hline \multirow[t]{2}{*}{ Stock type } & \multirow[t]{2}{*}{ Sub-group } & \multirow[t]{2}{*}{ Average weight (kg) } & \multirow[t]{2}{*}{$\begin{array}{l}\text { Drinking water requirement } \\
\text { (L/head/day) }\end{array}$} & \multicolumn{2}{|c|}{$\begin{array}{l}\text { Service water requirement } \\
\text { (L/head/day) }\end{array}$} \\
\hline & & & & Industrial system & Grazing system \\
\hline \multirow[t]{6}{*}{ Sheep } & Weaners & $15-20$ & $3.6-5.2$ & 2 & 0 \\
\hline & Adult dry sheep: grassland (saltbush) & $40-50$ & $2-6(4-12)$ & 5 & 5 \\
\hline & Ewes with lambs & $36-45$ & $4.0-6.5$ & 5 & 5 \\
\hline & Lactating meat ewe & $40-130$ & $9.0-10.5$ & 5 & 5 \\
\hline & Gestating dairy ewe/ram & - & $4.4-7.1$ & 5 & 5 \\
\hline & Lactating dairy ewe & 36 & $9.4-11.4$ & 5 & 5 \\
\hline Goats & Lactating & 27 & $7.6-11.9$ & 5 & 5 \\
\hline \multirow[t]{4}{*}{ Beef cattle } & Feedlot cattle: backgrounder & $200-680$ & $15-40$ & 2 & 0 \\
\hline & Feedlot cattle: short keep & & $27-55$ & 11 & 5 \\
\hline & Lactating cows: grassland (saltbush) & & $40-100(70-140)$ & 11 & 5 \\
\hline & Dry cows, bred heifers and bulls & 680 & $22-54$ & 11 & 5 \\
\hline \multirow{4}{*}{ Dairy cattle } & Milking cows & 680 & $68-155$ & 22 & 5 \\
\hline & Dairy calves (1-4 months) & $200-250$ & $4.9-13.2$ & 0 & 0 \\
\hline & Dairy heifers (5-24 months) & $350-450$ & $14.4-36.6$ & 11 & 4 \\
\hline & Dry stock & $400-550$ & $35-80$ & 22 & 5 \\
\hline \multirow[t]{4}{*}{ Swine } & Weaner & $5-35$ & $1.0-3.2$ & 5 & 0 \\
\hline & Feeder pig & $18-37$ & $3.2-10$ & 50 & 25 \\
\hline & Gestating sow/boar & - & $13.6-17.2$ & 50 & 25 \\
\hline & Lactating sow & 175 & $18.1-22.7$ & 50 & 25 \\
\hline \multirow[t]{4}{*}{ Chicken } & Broiler summer (winter, fall and spring) & $4-5$ & $0.45(0.28)$ & 0.09 & 0.09 \\
\hline & Broiler breeders & $1-3$ & $0.18-0.32$ & 0.09 & 0.09 \\
\hline & Laying hens & $1-3$ & $0.18-0.32$ & 0.15 & 0.15 \\
\hline & Pullets & $0.5-1$ & $0.03-0.18$ & 0.01 & 0.01 \\
\hline \multirow[t]{3}{*}{ Horses } & Small & $225-360$ & $13-20$ & 0 & 5 \\
\hline & Medium & $275-500$ & $26-39$ & 5 & 5 \\
\hline & Large & $450-700$ & $39-59$ & 5 & 5 \\
\hline Camel & Mid-lactation & 350 & $31.5-52.2$ & - & - \\
\hline
\end{tabular}

Table 2

Drinking water and service water requirements for livestock.

Modified from Attwood (1997); Chapagain and Hoekstra (2003); FAO (2006); Markwick (2007); Dennis (2008).

Additionally, service water are also required to clean the livestock production units, wash animals, cool the facilities, animals and their products as well as discharge the wastes. Table 2 shows some indications of different service water requirements. It can be seen that the water consumption in industrial systems is generally higher than that of grazing systems, owing to extra cooling and cleaning purposes of facilities. Specifically, pigs require a large quantity of water when kept in industrial "flushing systems", where service water requirements for washing manure down a gutter can be seven times higher than drinking water needs. Overall, the proportion of livestock production met by specialised and intensive industrial systems is rapidly increasing as these systems react faster to growing demand in production and consumption across the globe. Although the pace of expansion of livestock 
production may diminish, the growing trend will endure over the next 20 years (Gerber et al., 2005). Hence, if the recycled water can be properly treated to a standard that is appropriate for livestock production, considerable freshwater savings would be achieved, especially in intensive farming systems. While this new end use has not been extensively discussed globally, some areas such as the State of Victoria, Australia, have already formulated guidelines regarding the recycled water quality for use in livestock production. The Class A recycled water with tertiary treatment and pathogen reduction is recommended for general livestock (SGV, 2009).

\subsection{Use of recycled water for swimming pool}

Aquatic centres and swimming pools are major public facilities that provide significant benefits in terms of community development, sport, health and fitness to local residents. They require a large amount of water and energy to operate and maintain so that a number of public pools have been closed during the drought conditions. If no action were taken to mitigate inevitable water shortages in the future, there would be higher risks of closure for more pools in extreme weather situations, affecting the aquatic and recreational industry. Nevertheless, there is still a lack of information on water saving and reuse strategies in existing public aquatic centres around the world (Sydney Water, 2011). The major water consumption categories of a typical aquatic centre are depicted in Fig. 3. While strategies such as dual flush toilet systems, water saving and flow regulation devices in shower heads, and pool covers to reduce evaporation are commonly reported approaches being successfully implemented in many newly constructed aquatic centres, there will be a great potential in water saving and reuse when adopting measures on treating backwash water for use as pool make-up water.

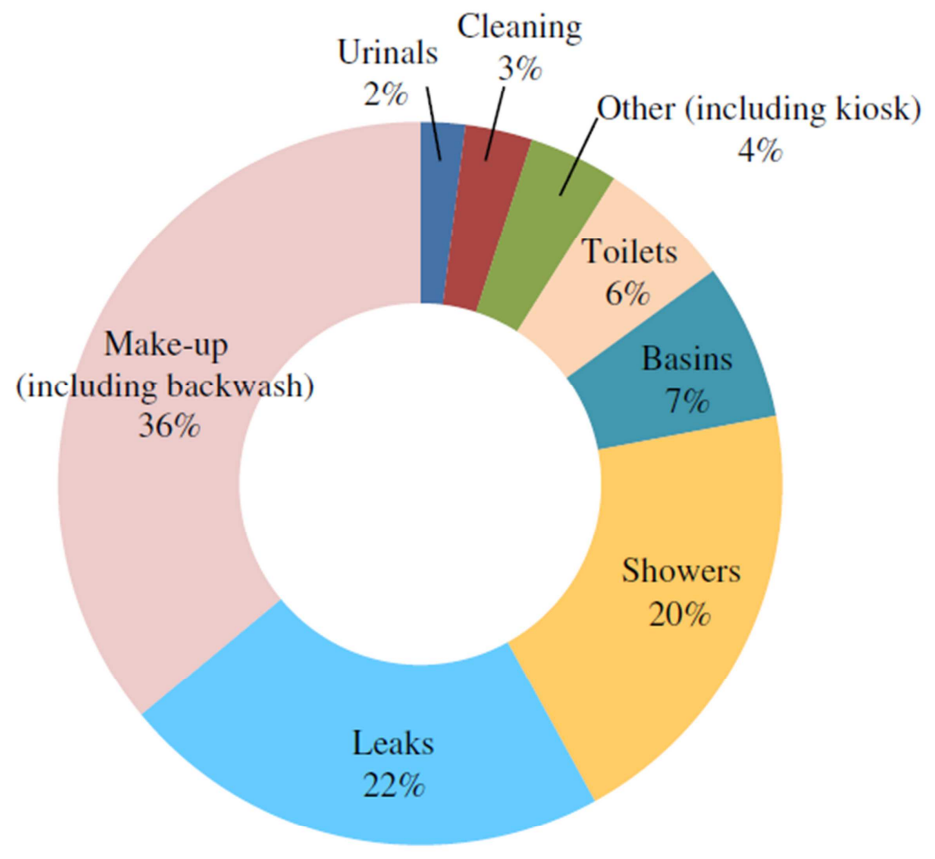

Fig. 3. Water use breakdown of a typical aquatic centre. (Modified from Sydney Water, 2011.)

However, the health and environmental risks associated with the use of treated backwash water vary greatly in terms of different water sources, end uses, treatment and management 
options, etc. (Table 3). To control the risks under low levels, it is advisable to use advanced treatment technologies such as reverse osmosis (RO), ultrafiltration (UF) and/or granular activated carbon (GAC), and conduct frequent monitoring and maintenance. For instance, the state of New South Wales, Australia, stipulates that the quality of recycled backwash water should meet the Australian Drinking Water Guidelines as pool water would likely to be accidentally swallowed during recreational activities (Environmental Health, 2012). Notably, when considering the use of these approaches, a lack of supporting information and understanding may hinder the implementation processes or cause the systems remain dysfunctional for a period of time. Hence, it is essential to ensure that adequate training, information, manuals and some level of feedback have been obtained on how to operate and maintain the strategy efficiently and effectively (Hazell et al., 2006). Besides, the staff members should also pass on water saving and reuse information to patrons and future customers, which could further improve water sustainability. There are successful applications of recycled backwash water in several Australian public aquatic centres, including pools in Penrith and Ryde city councils, New South Wales and centres in city of Whittlesea, Victoria. Nonetheless, the availability of well documented information is still limited (Hazell et al., 2006 and Chen et al., 2013b).

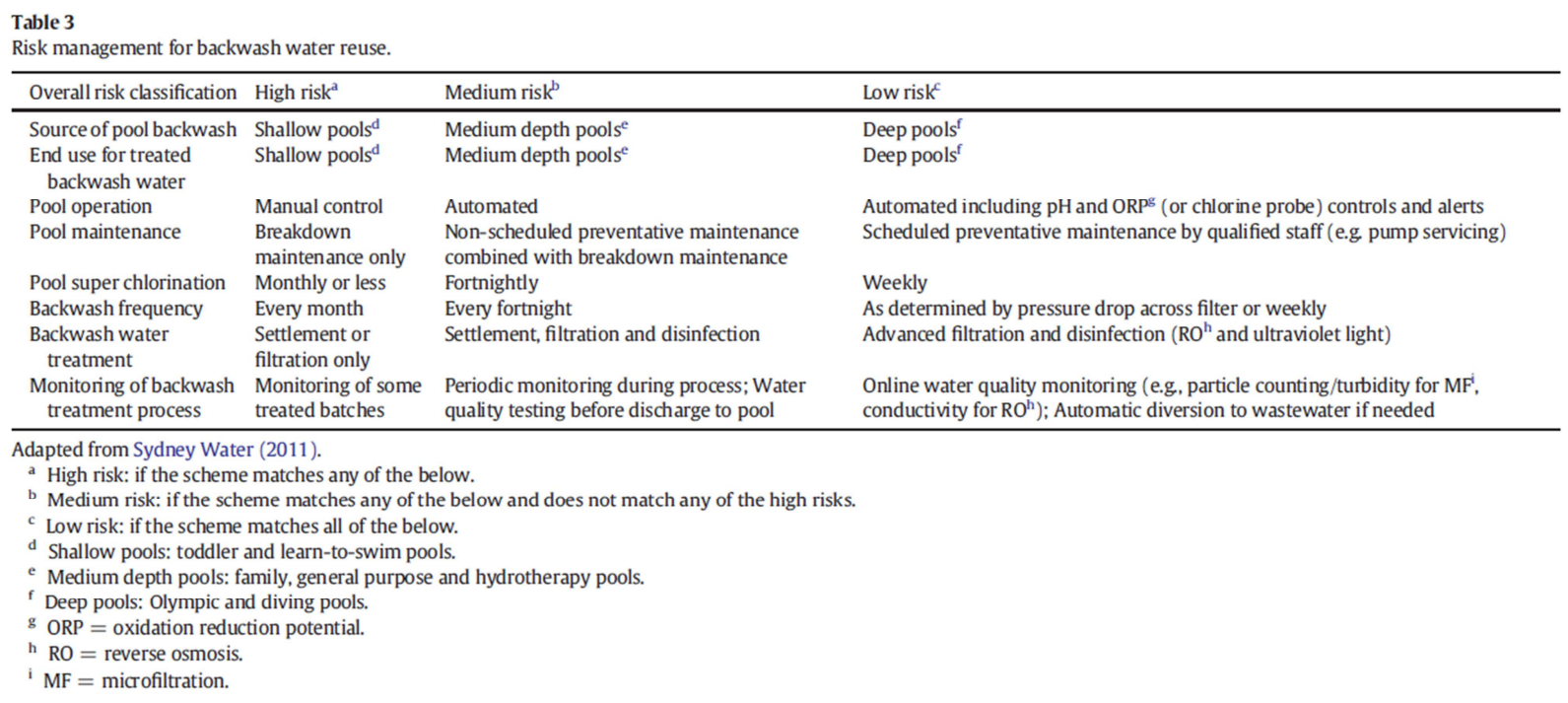

\section{Assessment analysis}

\subsection{Qualitative feasibility analysis}

The qualitative feasibility analysis is often used in the preliminary stages of decision making, which acts as a precursor to strategic management planning of recycled water schemes. It can be applied as a tool to identify the critical factors associated with the successful implementation of the schemes, including the project's internal aspects such as strengths and weaknesses, plus external factors including opportunities and threats (Mainali et al., 2011a). Table 4 summarises the qualitative profiles of three proposed new end uses of recycled water (SGV (State Government Victoria), 2009, Mainali et al., 2011b and Sydney Water, 2011). As can be seen, the end uses are apparently viable based on their foreseeable positive aspects (strengths and opportunities) to the community and environment. Future work still needs to find the ways and means to offset the weaknesses by distinct strengths and convert the threats to opportunities. As the descriptive results are unconvincing to some 
extent, there is a need for a more comprehensive quantitative assessment of new end uses with respect to technical, environmental, risk, social and economic considerations. As such, the optimal decision-making solutions for particular recycling schemes can be demonstrated and highlighted, which provide powerful guidance for sustainable water reuse management in the long term (Chen et al., 2012a and Chen et al., 2013b).

\begin{tabular}{|c|c|c|c|}
\hline \multirow{2}{*}{$\begin{array}{l}\text { Qualitative } \\
\text { feasibility } \\
\text { analysis }\end{array}$} & \multicolumn{3}{|l|}{ Potential new end uses } \\
\hline & Household laundry & Livestock using & Swimming pool \\
\hline Strengths & $\begin{array}{l}\text {-Washing clothes - a year round activity } \\
\text {-Significant laundry water consumption }\end{array}$ & $\begin{array}{l}\text {-Large water use on drinking and servicing } \\
\text { purposes in rural and regional areas }\end{array}$ & $\begin{array}{l}\cdot \text { - Little information on water reuse for } \\
\text { the option } \\
\text {-Large water consumption for pool } \\
\text { make-up water }\end{array}$ \\
\hline Opportunities & $\begin{array}{l}\text {-Expand the dual pipe water supply system } \\
\text {-Considerable freshwater saving and reduced effluent discharge } \\
\text {-Current recycled water (MF }{ }^{\mathrm{a}} \text { or advanced treatments) can be safely used } \\
\text {-Higher possibility of the public acceptance }\end{array}$ & $\begin{array}{l}\text {-Expand the dual pipe water supply system } \\
\text {-Considerable freshwater saving, especially in } \\
\text { intensive farming } \\
\text {-Current recycled water (tertiary and } \\
\text { disinfection) can be safely used } \\
\text { - Related guidelines in some areas have been } \\
\text { formulated }\end{array}$ & $\begin{array}{l}\text {-Considerable freshwater saving and } \\
\text { avoidance of sewage discharge } \\
\text {-Reduced health risks via improved } \\
\text { water quality and system management } \\
\text { - Lower risks of closure of some pools in } \\
\text { extreme weather conditions }\end{array}$ \\
\hline Weaknesses & $\begin{array}{l}\text {-Close human contact } \\
\text {-Need of extra taps to connect the dual pipe system to laundry } \\
\text {-Lack of safety data and relevant guidelines } \\
\text { - Lack of comprehensive quantitative assessment }\end{array}$ & $\begin{array}{l}\text {-Health risk concerns } \\
\cdot \text {-Need of extra taps to connect the dual pipe } \\
\text { system to stockyards } \\
\cdot \text {-Variety in water needs at different } \\
\text { stockyards } \\
\text { - Lack of comprehensive quantitative } \\
\text { assessment }\end{array}$ & $\begin{array}{l}\text { - Close human contact } \\
\text {-Strong public objection to the end use } \\
\text {-Additional costs on water quality } \\
\text { improvement } \\
\text { - Frequent water quality monitoring and } \\
\text { system maintenance }\end{array}$ \\
\hline Threats & $\begin{array}{l}\text {-Distrust the quality of water and concerns about health issues } \\
\text {-Water hardness forming scum } \\
\text {-Public concems on colour, odour, potential damage to clothes (e.g., iron } \\
\text { staining garments) and washing machines, and increased cost }\end{array}$ & $\begin{array}{l}\text {-Colloidal suspensions of oils and greases } \\
\text {-Livestock illness and discomfort (e.g., salinity } \\
\text { and water hardness) Suspicion and distrust } \\
\text { from farmers } \\
\text {-Staff reluctance due to close human contact } \\
\text { with recycled water }\end{array}$ & $\begin{array}{l}\text {-Requirement of advanced treatment } \\
\text { technologies }\left(\mathrm{e} . \mathrm{g} ., \mathrm{RO}^{\mathrm{b}}\right) \text { to produce high } \\
\text { quality water } \\
\text { •Need of adequate staff training } \\
\text {-Public concerns on colour, odour and } \\
\text { disease transmission } \\
\text {-Difficulty in acquiring public } \\
\text { acceptance }\end{array}$ \\
\hline
\end{tabular}

\subsection{Quantitative analysis for prioritisation of management options}

The procedures regarding the quantitative analysis of the proposed new end uses of recycled water include: i) consideration of specific management alternatives related to each new end use; ii) selection of key criteria that might affect the implementation of new end uses; iii) application of multi-criteria analysis; iv) recommendation of preferred option(s); v) communication, review, monitoring and reporting (Chen et al., 2012a).

\subsubsection{Management options}

1) Baseline scenario.

This scenario identifies the "business as usual" projection and can be regarded as a hypothetical reference case. It simply projects the future recycled water end uses based on existing recycling schemes (e.g., toilet flushing, garden watering and car washing). In other words, the baseline for a newly recycled water project reasonably presents the recycled water use activities that would occur in the absence of the proposed new end uses (laundry, livestock using or swimming pool). Thus, the baseline scenario can be used to compare and determine whether a new end use of recycled water is additional, and the additional savings and benefits achieved by the implementation of new end use activity (CDM, 2008).

2) Do-something options. 
This step is to identify all plausible alternative scenarios which can deliver outputs or services with comparable quality and properties to the proposed new end use project activity. Specifically, some scenarios include the selection of different equipment and/or facilities. For instance, the washing machines in households possess a number of different characteristics (e.g., loading type and capacity, water and energy consumption per wash, and brand and model name). A scenario regarding the adoption of front loading washing machine may involve with less water, energy and detergent consumption, but higher initial cost and inconvenience of loading and unloading clothes, compared with the use of top loaders (Bansal et al., 2011, Gato-Trinidad et al., 2011 and Chen et al., 2012a). Likewise, in livestock feeding and servicing industry, a scenario in which the intensive farming system instead of grazing system is employed, may relate to larger amount of water requirement, higher capital, maintenance and staff training costs, but greater production efficiencies (Gerber et al., 2005). For swimming pools, the installation of water efficient facilities such as dual flush toilets and filtration systems is likely to minimise water consumption and environmental footprint but induce additional investments simultaneously (Hazell et al., 2006).

Besides, some scenarios are also associated with the use of advanced treatment technologies to achieve different recycled water quality. Currently, although the Class A recycled water which undergoes tertiary treatment such as microfiltration (MF), ultraviolet disinfection for pathogen reduction, is generally regarded to be protective of the environment, public and animal health and food safety (O'Toole et al., 2009), more advanced techniques are supposed to be discussed to further improve the recycled water reliability and community acceptance. For example, some studies indicated that zeolites are good materials for water purification due to the advantages of low cost, operational simplicity and unique compositions for high level of ion-exchange, adsorption and regeneration. At tertiary treatment stage, the traditional system equipped post-treatment using zeolite column could significantly improve the effluent quality, especially the removal of ammonium in wastewater ( $\mathrm{Li}$ et al., 2007 and Widiastuti et al., 2008). After usage, zeolites are able to be regenerated for reuse purposes. Since the cost of chemical regeneration could be relatively high, some hybrid biological-ion exchange systems have been developed, where ammonium ions are initially absorbed by zeolites and bacteria attached to zeolite surface can subsequently convert ammonium to nitrite and nitrate nitrogen, contributing to bioregeneration of zeolites without the use of chemical regenerants. It was found that zeolites also have the ability to remove $\mathrm{PO}_{4}{ }^{3-}$ and enhance the sedimentation rate by the stable floc formation (Chung et al., 2000 and Kimochi et al., 2008). Besides, the potential of zeolites to remove bacteria and organic matter has been reported as well (Bowman, 2003).

Comparatively, other studies applied a MF-activated carbon (AC) system, either a GAC filter or a powdered activated carbon (PAC) suspension, rather than MF alone as tertiary treatment, which demonstrated better removal efficiency on synthetic organic chemicals and natural organic matters that cause taste, odour and colour. Similar to zeolites, as replacing AC in adsorptive column is relatively cumbersome and expensive, many systems adopt hybrid biological GAC/PAC filter systems where the media is operated essentially under low flux mode to support high heterotrophic and nitrifying biomass. In addition, compared with posttreatment $\mathrm{AC}$ units, the pre-treatment and hybrid configurations show possibility to control the AC age and mitigate membrane fouling (Kim et al., 2009 and Stoquart et al., 2012). However, the addition of zeolite or AC in wastewater treatment would probably lead to a longer contact time (5 to $20 \mathrm{~min}$ ) and therefore a lower flux rate, and introduce additional installation and usage fees. Another advanced approach is to use MF-Reverse Osmosis (RO) 
treatment system, which is able to produce recycled water of potable water quality. This could be regarded as a much reliable option for swimming pools owing to the potential close contact of treated backwash water with human body. The MF-RO system enables the water to be filtered, and most importantly, the dissolved salts (e.g., sodium and chloride) could be removed from the water during the backwash process, allowing it to be put back into the pool or used for other purposes such as irrigation and toilet flushing. Remarkably, both the installation fees and life cycle cost of RO are relatively high as the energy consumption is expected to be around $1.1 \mathrm{kWh} / \mathrm{m}^{3}$ compared with $0.23 \mathrm{kWh} / \mathrm{m}^{3}$ of MF (Côté et al., 2005). In spite of a long cost-recovery period, when the system is fully functioning, there will be no need of sewage discharge system as all backwash water in the pool is able to be treated and supplemented for pool make-up, saving approximately $52 \mathrm{~kL}$ of freshwater per year (Hazell et al., 2006). The system also has positive effects on the environment in long term. However, appropriate operation and maintenance would also be needed to keep long term performance of these advanced treatment technologies.

\subsubsection{Evaluation criteria}

This step identifies relevant evaluation criteria by which management alternatives on end uses would be judged. To ensure comprehensiveness and objectiveness of the assessment, it is advisable to take into account of relevant technical, environmental, health risks, social and economic aspects of alternatives appropriately in the decision making procedure. Technical indexes generally refer to recycled water availability and operability. On the one hand, water availability analyses incorporate detailed calculations on supply-demand relationship, service coverage, continuity and accessibility. Specifically, the supply-demand analysis is to identify the amount of recycled water needed in a certain area (e.g., household, farm and aquatic centre) for basic end use activities on a daily, monthly or annual basis. The service coverage reflects the size of the population/livestock that receives recycled water supply compared to the size of population/livestock without the service in that area while the water flow continuity and accessibility imply that recycled water should be available during working and livestock feeding time or at any time when it is required by households or aquatic centres. On the other hand, water operability analyses include the investigations on the ease of operation and maintenance and system flexibility to upgrade or extend, as well as risk and/or reliability assessment regarding the occurrence probability of treatment system malfunction (Ali, 2010).

Moreover, with respect to environmental aspects, highly treated recycled water is able to mitigate nutrient loads to surface or groundwater and reduce freshwater and chemical fertiliser consumption whereas poorly designed schemes may substantially alter the land use, affect the wetlands and endangered species and trigger adverse effects on surface or groundwater quality. Thus, several environmental indexes (e.g., greenhouse gas emissions, ecology, freshwater savings, energy consumption and recycled water quality) need to be quantified. The major greenhouse gases - carbon dioxide $\left(\mathrm{CO}_{2}\right)$, methane $\left(\mathrm{CH}_{4}\right)$ and nitrous oxide $\left(\mathrm{N}_{2} \mathrm{O}\right)$ - can be produced in wastewater treatment and power generation processes, which would lead to global warming and then rapid climate changes. Their greenhouse gas effect is typically weighted by global warming potential (unit: $\mathrm{t}_{2} \mathrm{e}$ ) which is dependent upon the timeframe of consideration, usually 100 years (Gupta and Singh, 2012 and Listowski et al., 2011). Additionally, the ecology generally refers to the impacts on land, surface water, groundwater, air, sediment and ecosystem as a result of reduced wastewater discharges. Furthermore, recycled water quality would not only impact the environmental ecosystem, but also be directly related to the risks on human health. Risk 
assessment can be conducted by either qualitative or quantitative approaches. A qualitative risk level (i.e., low, moderate, high or very high) can be estimated from the severity and expected frequency of the adverse event to human health and the environment while quantitative measurement involves detailed hazard identification, dose-response assessment, exposure assessment and risk characterisation using static or dynamic assessment models. Other integrated approaches such as the hybrid fuzzy-stochastic model and Bayesian network model could also be employed as alternative ways (Chen et al., in press).

With regard to social indexes, public acceptance, political support and educational opportunities are the main components to be considered for smooth expansion and development of recycled water supply and new end uses in local communities. Hence, research surveys on non-users, perspective users and current users are encouraged to be performed for understanding the holistic public knowledge, behaviour and attitude about water saving and recycled water use, and the impacts as well as measures that people are concerned when implementing the new end uses. Political support is relevant to the rebate, subsidy and policies from water authorities, providers or the government decision makers on the adoption of new water resource strategies. Educational opportunities include the education campaigns, offered information (e.g., leaflets, brochures and articles on newspapers/magazines), personal communications and workshops that could be provided to increase the public comprehension on the importance/advantage of recycled water as an alternative water resource (Chen et al., 2013c). For economic indexes, it is recommended to consider both the internal factors (e.g., capital, operational and maintenance costs, and recycled water affordability) and external factors (e.g., personal health and financial savings from reduced diseases and work/school absenteeism avoided) whenever possible. As there is typically no explicit market for external influences, the primary target is to quantify the internal factors of different reuse options in terms of monetary units. More precisely, capital cost embodies the initial investment and installation fees on wastewater treatment and supply facilities as well as end user devices while operational and maintenance costs represent the continuous investment over the whole running process (Urkiaga et al., 2008). The affordability index reflects whether the price of recycled water is affordable to householders, farmers, workers and/or consumers, which mainly depends on the annual income and recycled water tariff. Nevertheless, as a result of uncertainties existed in environmental (e.g., climate, geographical and water availability), demographical and economical conditions at different regions and/or time periods, the assessment data collection process would be time consuming and somewhat challengeable, which requires detailed site investigations, recycled water quality monitoring, analyses and reviews as well as extensive public surveys.

\subsubsection{Multi-criteria analysis (MCA) in decision making}

The adoption of MCA methodology as the last procedure in phase 2 of assessment framework is to investigate the tradeoffs among these selected multiple conflicting criteria and then obtain rankings of different management alternatives under certain mathematical algorithms. From the computerised MCA simulation, the least preferred options towards one/several end use(s) could be quickly eliminated whereas the superior alternatives can be further discussed. This can provide a powerful guidance for sustainable water recycling and reuse management in the long term as it is possible to suggest how much a successful strategy could benefit the decision maker in exploitation, planning, development and expansion stages of new end uses. With these highly persuasive data, the public acceptability and trust on recycled water 
applications can also be greatly improved, which in turn further accelerate the booming of potential recycled water markets (Abrishamchi et al., 2005 and Chen et al., 2012b).

Initially, the scoring process aims to generate a matrix where elements represent evaluation scores of each option against each criterion. As the criteria are fundamentally different by nature and their values are normally manifested in varied forms (e.g., quantitative estimates and qualitative judgments) with different unit scales (e.g., monetary, volume and concentration units), classification and normalisation processes might be required to make the final score dimensionless thereby enabling comparison. For qualitative data, 5-, 7-, 9- and 11point scale systems have been reportedly used in different locations of Australia, where higher values represent more positive effects (Coutts, 2006). Since qualitative information is likely to introduce bias towards or against certain facilities or technologies due to inevitable personal perceptions, quantitative data are supposed to be employed to the great extent. Secondly, to embody varying degrees of concern on different evaluation criteria in decision making, weighting process becomes essential in MCA which is to assign higher weights to more important criteria and smaller weights to less important criteria. Although recent works have given more attention to recycled water quality and operational and maintenance cost (Ngo et al., 2009), or highlighted the importance of environmental performances (Chen et al., 2013b), the case-specific context can facilitate the need for differential weighting. Yet in some cases, due to lack of sufficient expertise, decision makers might be less confident in assigning specific weight to each criterion, making the weight values be highly variable. Thus, to reduce man-made errors, some sophisticated models (e.g., random weight model, rank order weight generation model and response distribution weight model) have been developed. For instance, the rank order weight generation model (ROWG) is capable of evaluating all possible combinations of weights via computerised simulation with a given precedence order in the criteria. The competing options could be then narrowed down through statistical weight results (Chen et al., 2012a).

At the heart of MCA is the aggregation process which must be carefully assessed to ensure the results of the evaluation are consistent with the preferences of the decision makers. There are a number of aggregation algorithms, including weighted summation, multi-attribute utility theory (MAUT), compromise programming, analytical hierarchy process, ELECTRE, PROMETHEE and cooperative game theory. Despite the fact that the aggregation functions are distinct with different levels of calculation complexity and accuracy, a core procedure is to incorporate weight information with the evaluation matrix scores to attain a result. Hajkowicz and Higgins (2008) found strong agreement between different MCA algorithms used for water resource management. Hence, in many applications there is no overwhelming reason to adopt one MCA technique over another approach. The ease of understanding, transparency and preciseness would be the prime concerns. In circumstances of determining the robustness of the options, it is suggested to use more than one MCA technique (Alvarez-Guerra et al., 2009). The detailed applications of MAUT and PROMETHEE in recycled water new end uses especially the household laundry are shown in Chen et al., 2012a and Chen et al., 2013b. Lastly, with a fixed set of criteria values and a fixed set of weights, the statistical values of management options can be obtained. According to the ranking order, the least preferred options can be eliminated and the optimal option(s) for new end use implementation should be intensively investigated. Additionally, when adopting a single set of weights, sensitivity analyses of weights can be effective to minimise uncertainty in scores and guarantee the reliability and accuracy of rankings and the final 
decision. Meanwhile, continuous communications and conversations among stakeholders, local authorities, water providers and community members might also be essential.

\subsection{Decision-making plan}

At management stage, this phase involves the clarification of water reuse goals associated with the recommended option(s), conduct of risk communication to increase public awareness, and completion of reporting, technological monitoring and review for organisational entities' approval. Based on MCA results, some targeted water reuse goals on superior alternatives that are expected to accomplish in short term can be established and verified through committee meetings and discussion as well as external counselling and resources. A detailed assessment report can be then presented to relevant government departments, which should include the major strengths and barriers regarding the new end use strategy implementation and expansion, together with periodic review and evaluation plans in future operational stages.

\section{Conclusions}

The successful establishment and implementation of new applications in existing or future schemes may depend on a series of issues, comprising technical concerns, environmental impacts, health risks, social attitudes and economic statuses. As a systematic procedure for analysis of multiple constraints is still lacking, this paper proposed a novel framework and methodology for the holistic assessment of three possible new end uses, including household laundry, livestock feeding and servicing, and swimming pool. It was convinced that the methodology and findings would not only offer fundamental information for the subsequent model design and construction but also benefit the decision making with a clear, sound and reliable strategy. Consequently, the whole decision making process for recycled water new end use exploration and implementation would lead to a more robust, efficient and credible solution for prospective water market.

\section{Acknowledgement}

This work was funded by Australian Research Council (ARC) Industry Linkage Grant (LP100100494).

\section{References}

Abrishamchi A, Ebrahimian A, Tajrishi M, Mariño MA, Hon M. Case study: application of multicriteria decision making to urban water supply. J Water Resour Plann Manage 2005;131:326-35.

ABS (Australian Bureau of Statistics). Household appliances. Environmental issues: energy use and conservation, Mar 2011. Available from:

http://www.abs.gov.au/ausstats/abs@.nsf/Lookup/4602.0.55.001Main+Features6Mar+2011, 2011.

ABS (Australian Bureau of Statistics). Water account Australia 2010-11. Available from: http://www.abs.gov.au/ausstats/abs@.nsf/mf/4610.0, 2012.

Ali F. Development of water stress index as a tool for the assessment of water stress areas in the metropolitan Jakarta. Paper presented at the 16th Annual International Sustainable Development Research Conference, Hong Kong; 2010.

Alvarez-Guerra M, Viguri JR, Voulvoulis N. A multicriteria-based methodology for site prioritisation in sediment management. Environ Int 2009;35:920-30. 
Alvarez-Guerra M, Canis L, Voulvoulis N, Viguri JR, Linkov I. Prioritization of sediment management alternatives using stochastic multicriteria acceptability analysis. Sci Total Environ 2010;408:4354-67.

Anderson J. Walking like dinosaurs: water, reuse and urban jungle footprints. Water Recycling Australia, AWA 2nd National Conference, Brisbane, Australia; 2003.

Angelakis AN, Durham B. Water recycling and reuse in EUREAU countries: trends and challenges. Desalination 2008;218:3-12.

Asano T, Bahri A. Global challenges to wastewater reclamation and reuse. On Water Front 2011;2:64-72.

Attwood CM. Dry sheep equivalents for comparing different classes of livestock. Agriculture notes. Available from: http://www.agronomy.com.au/download/DSEratings.pdf, 1997.

Babin R. Assessment of factors influencing water reuse opportunities in Western Australia. [Dissertation] University of Southern Queensland; 2005.

Bansal P, Vineyard E, Abdelaziz O. Advances in household appliances - a review. Appl Therm Eng 2011;31:3748-60.

Bertone E, Stewart RA. Framework for enhancing the supply-demand balance of a tri-supply urban water scheme in Australia. Water 2011;3:976-87.

Bowman RS. Application of surfactant-modified zeolites to environmental remediation. Microporous Mesoporous Mater 2003;61:43-56.

Brissaud F. Technologies for water regeneration and integrated management of water resources. In: Sabater S, Barceló D, editors. Water scarcity in the Mediterranean: perspectives under global change. Heidelberg, Berlin: Springer-Verlag; 2010.

CDM (Clean Development Mechanism) Rulebook. Large-scale. Baselines and additionality. Available from:http://cdmrulebook.org/83, 2008.

Chapagain AK, Hoekstra AY. Virtual water flows between nations in relation to trade in livestock and livestock products. Value of water research report series No. 13; 2003.

Chen Z, Ngo HH, Guo WS, Listowski A, O'Halloran K, Thompson M, et al. Multi-criteria analysis towards the new end use of recycled water for household laundry: a case study in Sydney. Sci Total Environ 2012a;438:59-65.

Chen Z, Ngo HH, Guo WS. A critical review on sustainability of recycled water schemes. Sci Total Environ 2012b;426:13-31.

Chen Z, Ngo HH, GuoWS. A critical review on the end uses of recycledwater. Crit Rev Environ Sci Technol 2013a;43:1446-516.

Chen Z, Ngo HH, Guo WS, Wang XC. Analysis of Sydney's recycled water schemes. Front Environ Sci Eng 2013b;7:608-15.

Chen Z, Ngo HH, Guo WS, Wang XC, Miechel C, Corby N, et al. Analysis of social attitude to the new end use of recycled water for household laundry in Australia by the regression models. J Environ Manage 2013c;126:79-84.

Chen Z, Ngo HH, Guo WS. Risk control in recycled water schemes. Crit Rev Environ Sci Technol 2013. http://dx.doi.org/10.1080/10643389.2012.672085. [in press].

Chung YC, Son DH, Ahn DH. Nitrogen and organics removal from industrial wastewater using natural zeolite media. Water Sci Technol 2000;42:127-34.

Côté $\mathrm{P}$, Siverns S, Monti S. Comparison of membrane-based solutions for water reclamation and desalination. Desalination 2005;182:251-7.

Coutts SS. A recycled water strategy for regional urban communities. Desalination 2006;188:185-94.

Dennis B. Livestock water supplies, fact sheet of government of South Australia. Available from: http://www.pir.sa.gov.au/_data/assets/pdf_file/0008/37763/ Livestock_Water_Supplies.pdf, 2008. 
DOH (Department of Health). Guidelines for validating treatment processes for pathogen reductionsupporting class A recycled water schemes in Victoria. Available from:

http://docs.health.vic.gov.au/docs/doc/41FDFAB63422E5CFCA257B180077F489/

\$FILE/DHD\%2013\%202708\%20\%20Guidelines\%20for\%20validating\%20treatment\%20processes\%20f or\%20pathogen\%20reduction\%20(Web\%20version).pdf, 2013.

DWR (Department of Water Resources). California water plan. Volume 2 - resource management strategies. Chapter 11 - recycled municipal water. Available from:

http://www.waterplan.water.ca.gov/docs/cwpu2009/0310final/v2c11_recycmuniwtr_cwp2009 .pdf, 2009.

Environmental Health. Fact sheet - reuse and recycling of swimming pool backwash water. Available from:http://www.health.nsw.gov.au/environment/factsheets/Pages/swimming-poolbackwash.aspx, 2012.

FAO (Food and agriculture organization of the United Nations). Part V: livestock's role in water depletion and pollution. Livestock's long shadow, environmental issues and options; 2006. [Available from: http://www.fao.org/docrep/010/a0701e/a0701e00.htm].

Gato-Trinidad S, Jayasuriya N, Roberts P. Understanding urban residential end uses of water. Water Sci Technol 2011;64:36-42.

Gerber P, Chilonda P, Franceschini G, Menzi H. Geographical determinants and environmental implications of livestock production intensification in Asia. Bioresour Technol 2005;96:263-76.

Gupta D, Singh SK. Greenhouse gas emissions from wastewater treatment plants: a case study of Noida. J Water Sustain 2012;2:131-9.

Hajkowicz S, Higgins A. A comparison of multiple criteria analysis techniques for water resource management. Eur J Oper Res 2008;184:255-65.

Hazell F, Nimmo L, Leaversuch P. Best practice profile for public swimming pools - maximising reclamation and reuse. Perth, Western Australia: Royal Life Saving Society (WA Branch); 2006.

Kim KY, Kim HS, Kim J, Nam JW, Kim JM, Son S. A hybridmicrofiltration-granular activated carbon system for water purification and wastewater reclamation/reuse. Desalination 2009;243:13244.

Kimochi Y, Masada Y, Mikami Y, Tsuneda S, Sudo R. Tertiary treatment of domestic wastewater using zeolite ceramics and aquatic plants. Water Sci Technol 2008;58:847-51.

Lazarova V, Hills S, Birks R. Using recycled water for non-potable, urban uses: a review with particular reference to toilet flushing. Water Sci TechnolWater Supply 2003;3:69-77.

Lazarova V, Oelker G, Won W. Production of custom-made recycled water for various reuse purposes: lessons learned from one of the world's largest recycling facilities. Water Pract Technol 2012;7. http://dx.doi.org/10.2166/wpt.2012.052.

Li XM, Guo L, Yang Q, Zeng GM, Liao DX. Removal of carbon and nutrients from low strength domestic wastewater by expanded granular sludge bed-zeolite bed filtration (EGSB-ZBF) integrated treatment concept. Process Biochem 2007;42:1173-9.

Listowski A, Ngo HH, Guo WS, Vigneswaran S, Shin HS, Moon H. Greenhouse gas (GHG) emissions from urban wastewater system: future assessment framework and methodology. J Water Sustain 2011;1:113-26.

Mainali B, Ngo HH, Guo WS, Pham TTN, Wang XC, Johnston A. SWOT analysis to assist identification of the critical factors for the successful implementation of water reuse schemes. Desalin Water Treat 2011a;32:297-306.

Mainali B, Ngo HH, Guo WS, Pham TTN, Johnston A. Feasibility assessment of recycled water use for washingmachines in Australia through SWOT analysis. Resour Conserv Recycl 2011b;56:87-91.

Mainali B, Pham TTN, Ngo HH, Guo WS. Maximum allowable values of the heavy metals in recycled water for household laundry. Sci Total Environ 2013;452-453:427-32. 
Markwick G. Water requirements for sheep and cattle. New South Wales Department of Primary Industries. Available from

http://ruralresidentialliving.com.au/livestock/resource_downloads/Primefacts\%20Water\%20re quirements\%20for\%20sheep\%20and\%20cattle.pdf, 2007.

Ngo HH, Chuang H, GuoWS, Ho DP, Pham TTN, Johnston A, et al. Resident's strategy survey on a new end use of recycled water in Australia. DesalinWater Treat 2009;11:93-7.

NRC (National Research Council).Water reuse: potential for expanding the nation's water supply through reuse of municipal wastewater.Washington, DC: The National Academies Press; 2012.

O'Toole J, Sinclair M, Leder K. Transfer rates of enteric microorganisms in recycled water during machine clothes washing. Appl Environ Microbiol 2009;75:1256-63.

Pakula C, Stamminger R. Electricity andwater consumption for laundry washing by washing machine worldwide. Energy Effic 2010;3:365-82.

Savewater Alliance. Water use in home - laundry. Available from:http://www.savewater.com.au/how-to-save-water/in-the-home/laundry, 2012.

SGV (State Government Victoria). Reclaimed water use in livestock production. Recycling and waste management; 2009. [Available from: http://www.dpi.vic.gov.au/agriculture/farmingmanagement/recycling-and-waste-management/reclaimed-water-use-livestock-production].

Stoquart $C$, Servais $P$, Bérubé $P$, Barbeau B. Hybrid membrane processes using activated carbon treatment for drinking water: a review. J Membr Sci 2012;411-412:1-12.

SydneyWater. Best practice guidelines for water management in aquatic leisure centres. Available from:http://www.sydneywater.com.au/web/groups/publicwebcontent/documents/document/ zgrf/mdq1/ edisp/dd_045262.pdf, 2011.

UN (United Nations). Convention to combat desertification. UNCCD thematic fact sheet series No.2. Water scarcity and desertification. Available from: http://www.unccd.int/Lists/SiteDocumentLibrary/Publications/Desertificationandwater.pdf, 2010.

Urkiaga A, de las Fuentes L, Bis B, Chiru E, Balasz B, Hernández F. Development of analysis tools for social, economic and ecological effects of water reuse. Desalination 2008;218:81-91.

Van der Bruggen B. Chapter 3. The global water recycling situation. Sustainable water for the future. Water recycling versus desalinationAmsterdam, the Netherlands:Elsevier; 2010. p. 41-62.

Widiastuti N, Wu H, Ang M, Zhang DK. The potential application of natural zeolite for greywater treatment. Desalination 2008;218:271-80.

Wild D, BuffleMO, Cai JH.Water: amarket of the future. Available from:http://www.bhopal.net/petition/application/views/waterstudy_e.pdf, 2010.

WWO (World Water Organization). Water facts \& water stories from across the globe. Available from:http://www.theworldwater.org/water_facts.php, 2010.

YVW (Yarra Valley Water). Aurora Craigieburn West recycled water project. Available from:http://www.yvw.com.au/Home/Aboutus/Ourprojects/Completedprojects/Aurorarecycled water/index.htm, 2010. 